\title{
PAINTINGS BY AMERICAN ARTISTS
}




\section{THE AMERICAN ARTISTS SERIES}

Each volume uniform, printed from type on bandmade paper in limited editions and beautifully illustrated with photogravure plates.

\section{EARLIER VOLUMES}

GeORGE INNess. By Elliott Daingerfield . . . Out of print Fifty Paintings by George InNess . . . . . . . . \$25.00 Homer Martin. By Frank J. Mather, Jr. . . . . . 25.00 Fifty-Eight Paintings by Homer Martin . . . . 25.00 Alexander Wyant. By Eliot Clark . . . . . . . 25.00 Sixty Paintings by Alexander Wyant . . . . . 25.00 Ralph A. BlaKelock. By Elliott Daingerfield . . . . 17.50 Winslow Homer. By Kenyon Cox . . . . . . . 25.00 Albert Pinkham Ryder. By Frederic F. Sherman . 25.00 John H. Twachtman. By Eliot Clark . . . . . . 25.00 J. Francis Murphy. By Eliot Clark . . . . . . . 25.00

\section{AMERICAN PAINTERS OF YESTERDAY AND TODAY} BY FREDERIC F. SHERMAN

I 2 mo. Limited edition. Illustrated. Delivered $\$ 4.00$ Illuminating and well written. Interesting alike to the artist and the art lover. -Cincinnati Enquirer.

\section{LANDSCAPE AND FIGURE PAINTERS OF AMERICA} By FREDERIC F. SHERMAN

I 2 mo. Limited edition. Illustrated. Delivered $\$ 4.00$

Mr. Sherman searches for spiritual and intellectual significances. He helps us to recognize beauties and apprehend sentiment.

-Detroit Free Press.

\section{THE MODERN TENDENCY IN AMERICAN PAINTING} By CATHERINE BEACH ELY

Octavo. With many full-page reproductions of contemporary paintings. Limited edition of 325 copies. $\$ 8.75$ net, delivered. An account of the artists selected and a description of their pictures, enhanced by the deepęr note of personal acquaintanceship. -Cbicago Evening Post.

FREDERIC FAIRCHILD SHERMAN, PUBLISHER \8-SOA HWW YaRK-GIT 
Correspondence invited

Prices quoted on request

SMITHSONIAN

\section{JUL 311985}

\section{LIBRARIES}

\section{FREDERIC FAIRCHILD SHERMAN \\ S78 ADISON AVENUE \\ NEW YORK-ETY \\ 44 STate STreet WESTPORT, CONN.}




\section{OPHELIA}

\section{By ALBERT PINKHAM RYDER}

Panel. I 6 inches bigh by I $3 / 4$ inches wide.

One of the last pictures exhibited by the artist, appearing in the National Academy show of 1887 .

The finest of Ryder's figure pictures and one of his greatest works. It is a symphony in golden browns and yellows, relieved by notes of rose and white and green as they occur in the wreath of blossoms about Ophelia's head and the flowers and foliage lying in her lap. Its persuasive beauty seems like a reincarnation of all that was best in the finest interpretations of the role which one has witnessed upon the stage.

"The beauty of this picture is almost poignant. I think Shakespere would not wish for a more subtle interpretation." -Elliott Daingerfield.

"A leautifu! example of this artist's work." 


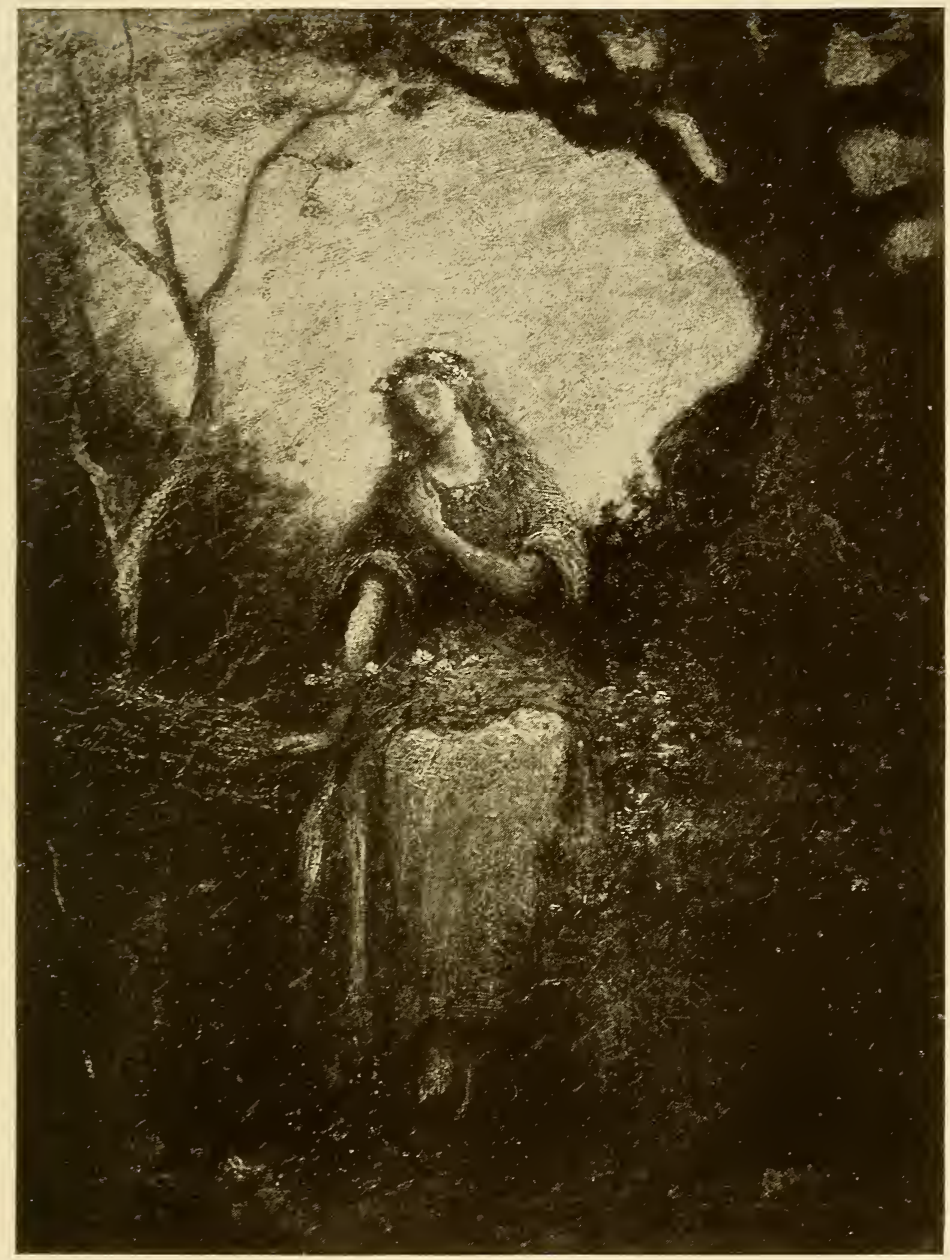




\section{SYLVAN DANCE}

\section{By ALBERT PINKHAM RYDER}

\section{Panel. 10 $3 / 8$ inches bigh by $141 / 4$ inches wide.}

Painted in the early 1890 's.

Formerly the property of Mr. Felix Hoffman, who purchased it from the artist.

In this scene Ryder has almost perfectly interpreted a fairylike vision of imaginative and emotional beauty in which rhythm, music and choice color are interwoven with such inimitable skill as to result in an idyllic poem of classic charm. The nude figure of the shepherd is one of the finest he ever drew and the tableau is certainly one of the most beautiful he ever contrived. The picture is full of the rich yellow and golden tones of the sunset hour.

For this work the artist composed the following lines of verse, which appear on the tablet on the frame,

"Oh, no, I have no voice or hand For such a song in such a land." 


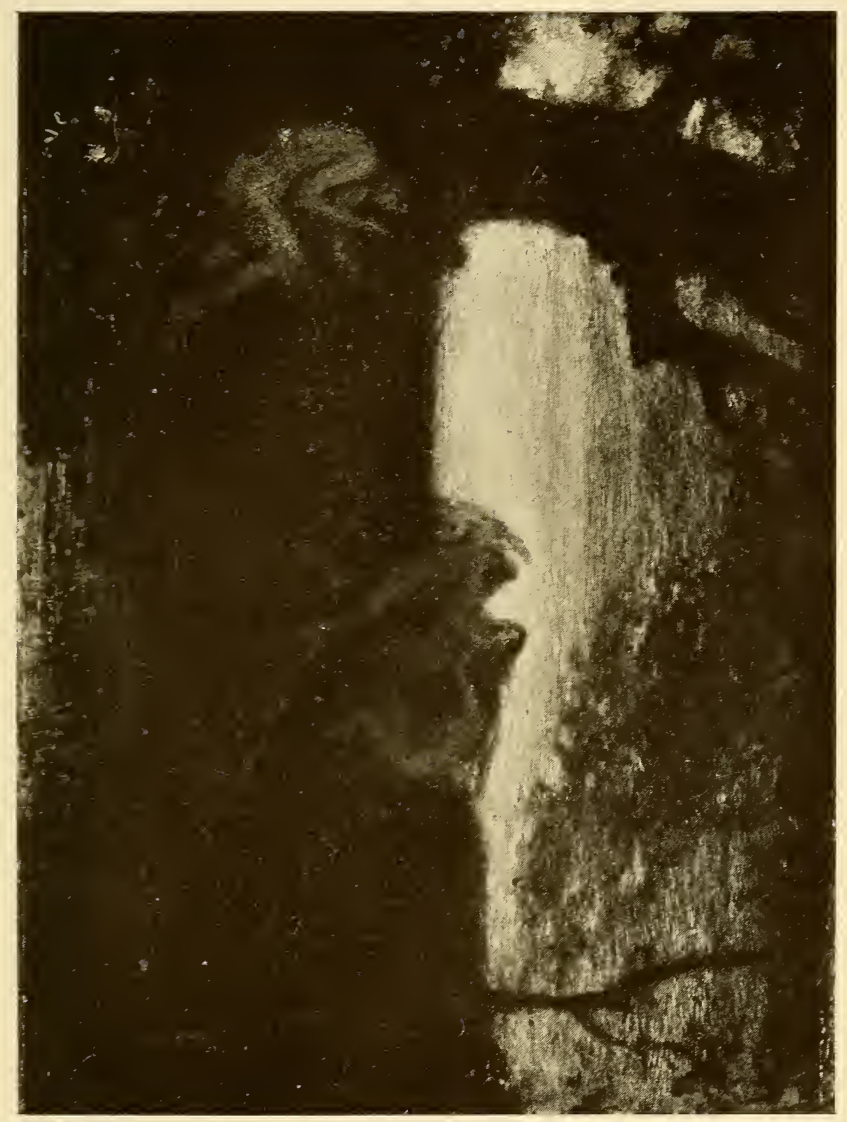




\section{MARINE WITH FULL MOON}

\section{By ALBERT PINKHAM RYDER}

Canvas. ro inches bigh by $\mathrm{I} 2$ inches wide. Signed at the lower left, "A. P. Ryder."

In this handsome little marine Ryder evokes the illimitable reach of the sea by the simple expedient of representing the sailboat as tacking directly away from the spectator into the distance, where at the horizon the ocean meets the sky. For all the ferment of the waves the picture is permeated with a sense of solitude and remoteness from the everyday turmoil and struggle of life, bringing a blessed feeling of relief to the observer and turning one's mind to the contemplation of the marvellous magnitude and incredible beauty of the mysteries of the universe. It differs from all the other marines in its slightly silvery quality - almost unique in the artist's seascapes. 


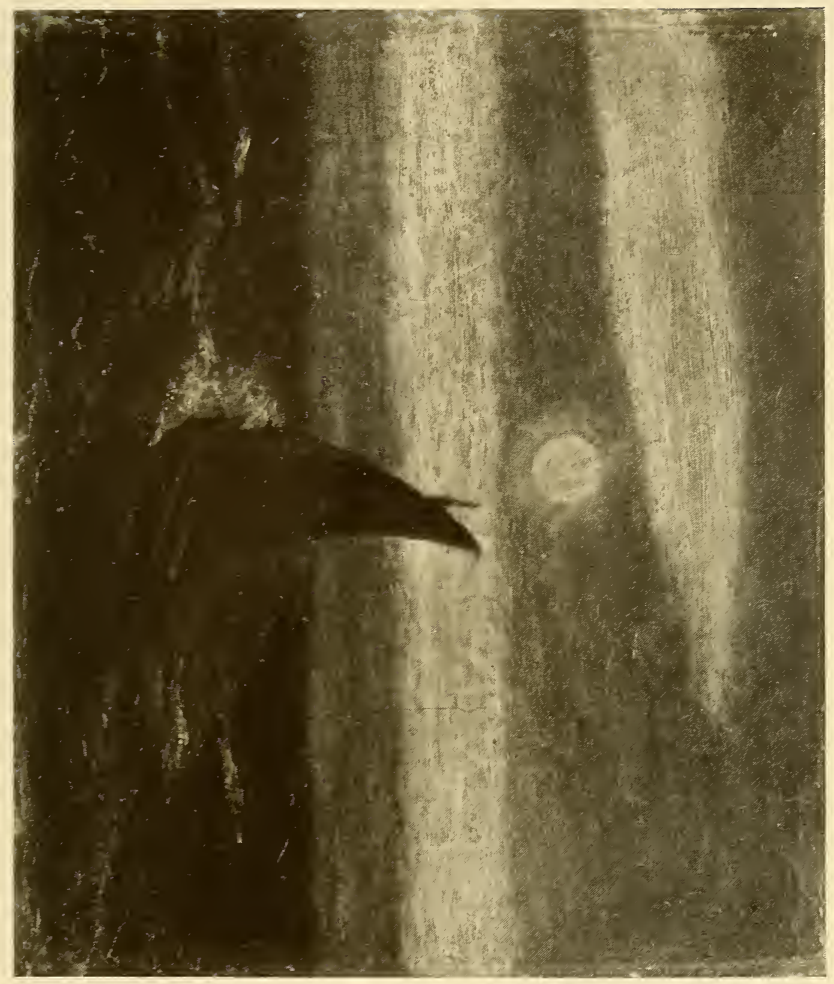




\section{THE ROAD OF LIFE}

\section{By ALBERT PINKHAM RYDER \\ Canvas. I 4 inches bigh by' 12 inches wide.}

One of the most beautiful of the artist's landscapes. The winding stream, the green meadow and the typical sky with its intriguing arrangement of cloud forms make a most impressive background for the aged, weary, white-haired and bearded traveller, staff in hand, resting by the side of the road that follows the stream. The coloring is very rich and pure and the picture lighter in hue than his customary works. 


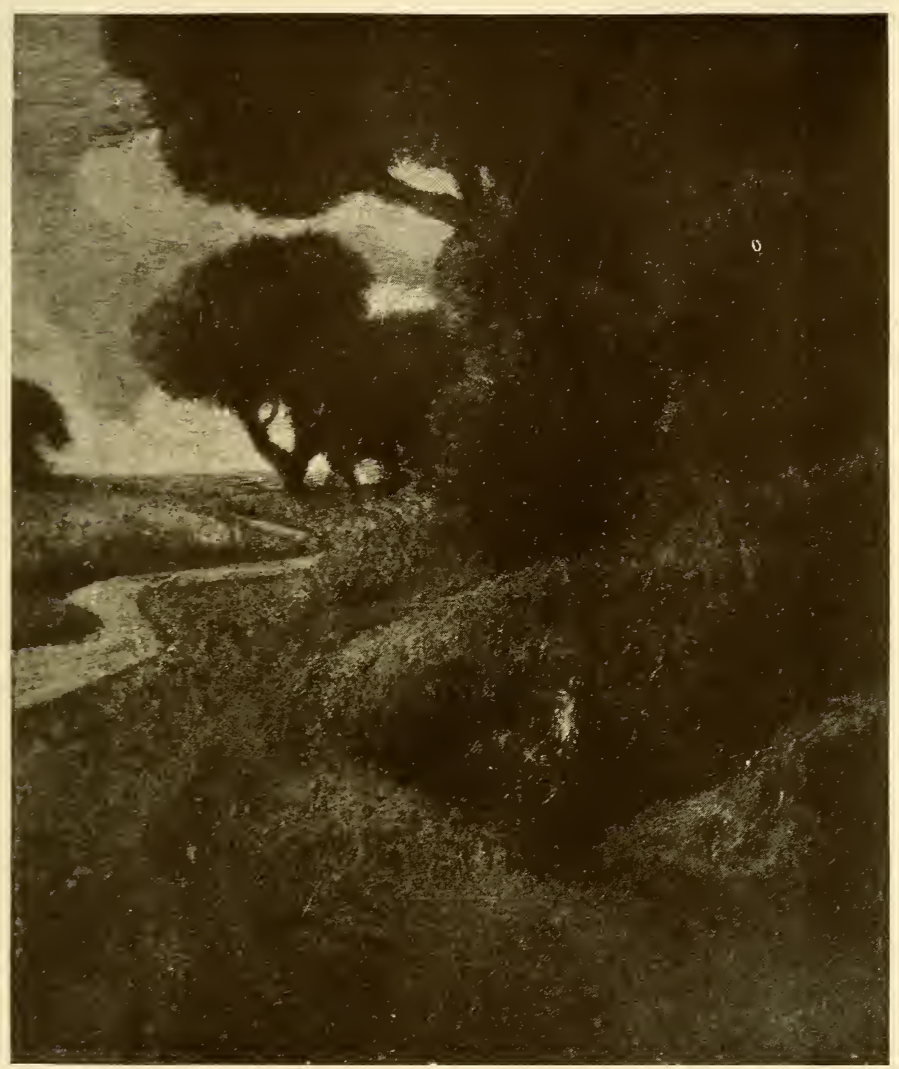




\section{PORTRAIT OF AN ARTIST \\ By FRANK DUVENECK}

Canvas. $2 \mathrm{I} / 2$ inches high by $\mathrm{I} 8$ inches wide. Signed at left (over the sitter's shoulder) with the monogram, "FD."

A summary sketch of a fellow student which has all of the authority of a finished portrait. While it is probably the product of a hurried hour in a classroom, it has all the quality of a "studio" work. The very poise of the head, the upward glance, confirm the belief that it is a strikingly truthful likeness of the virile young painter in a moment of satisfaction over some work he had in hand.

"After all is said, Frank Duveneck is the greatest talent of the brush of this generation."

-Jolnn Singer Sargent.

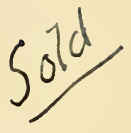




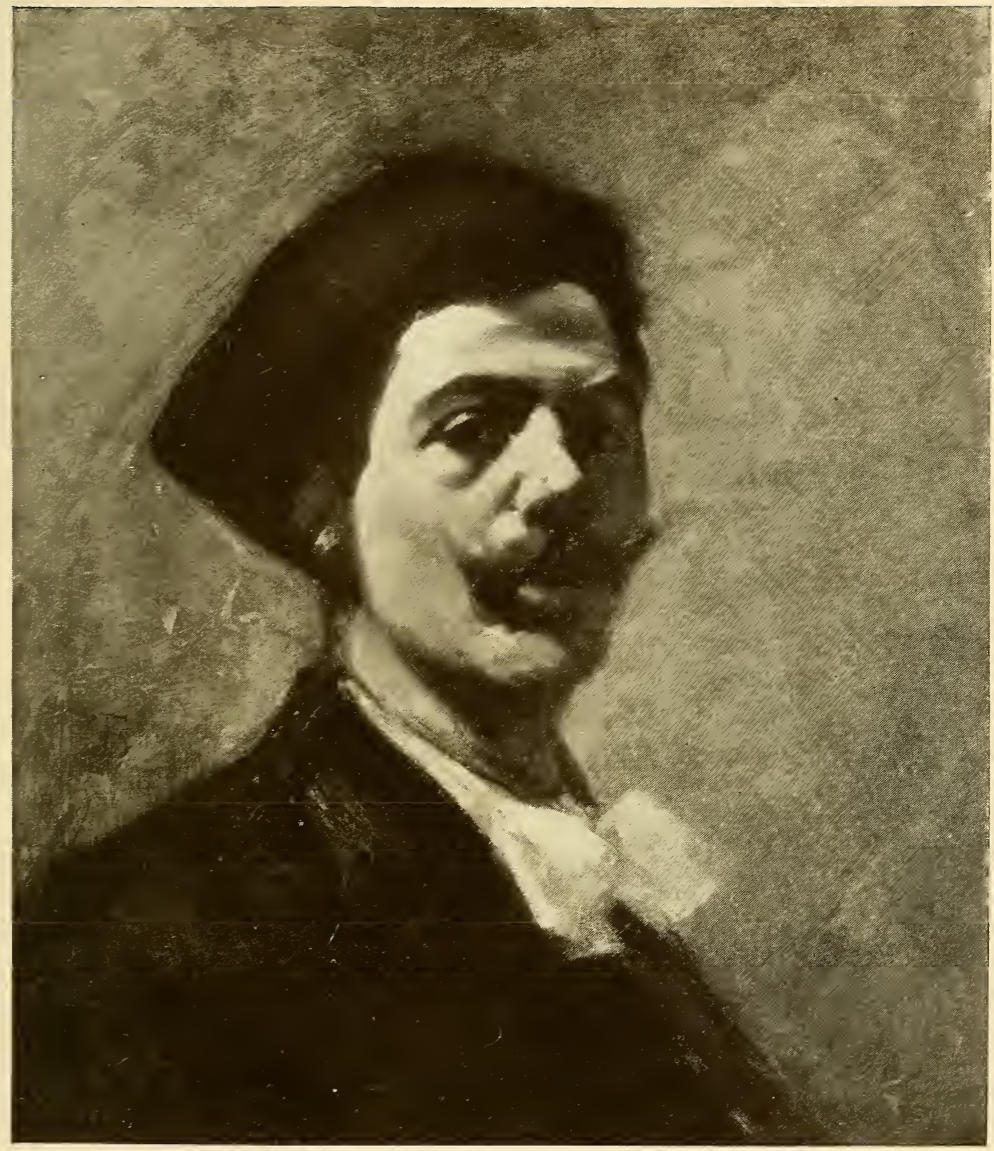




\section{LASSITUDE \\ By WYATT EATON}

Canvas. 2 I inches bigh by 19 inches wide.

Formerly the property of William M. Chase, the artist, who purchased it from Mrs. Eaton.

A fascinating study of a model resting against a greenish drapery in slumberous relaxation, the light falling upon the figure and emphasizing the graceful physical beauty of the supple form and the evanescent pearl and ivory tones of the nude flesh. 


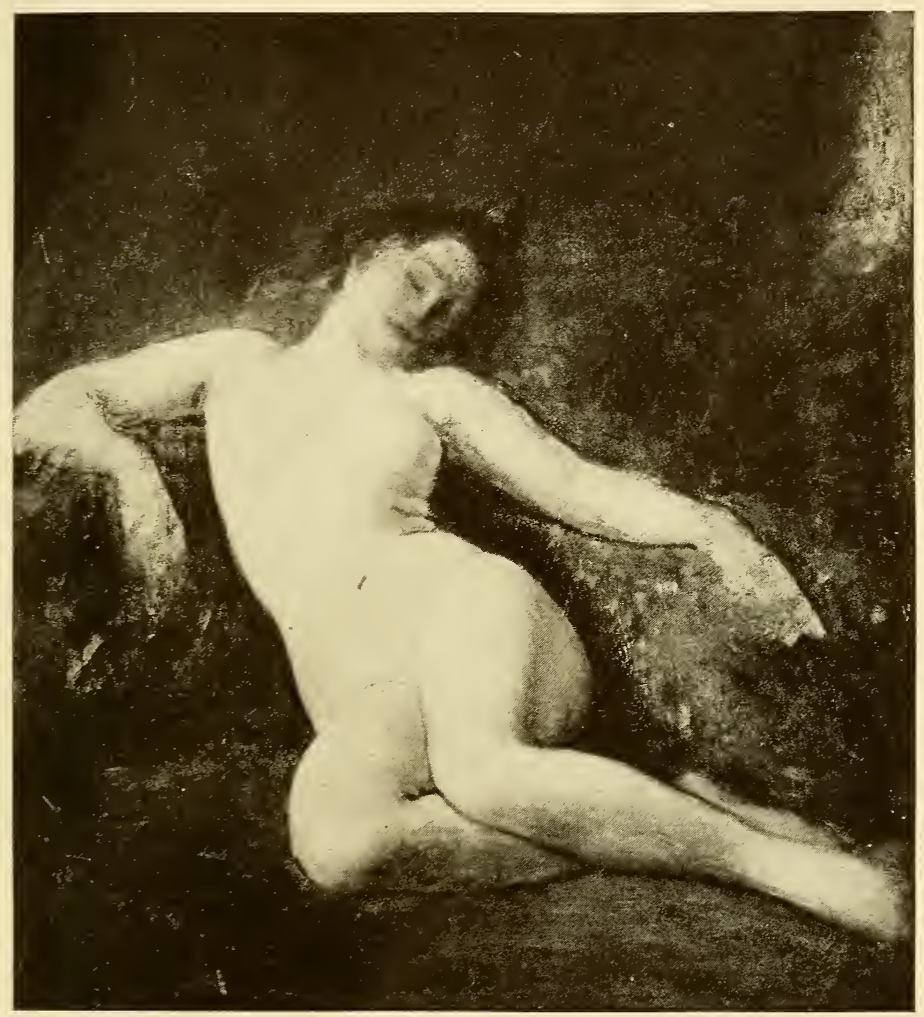




\section{FISHING BOATS AT ANCHOR}

\section{By' WILLIAM GEDNEY BUNCE}

Panel. $14^{1} / 2$ incloes bigh by 25 inches wide. Signed on the back and dated, "Wm. Gedney Bunce, Venice, '8 I."

This composition has an effect of spaciousness that provides a sympathetic setting for the group of boats in the foreground and the blending of the grayish-golden clouded sky with the golden gray of the quiet water provides a harmony of color as interesting as it is subtle. Painted as most of the artist's pictures are, on a mahogany panel, the wood itself is in places a part of the picture and gives it a gracious warmth of tone. Very loose and free in handling and to a considerable extent done with palette knife rather than the brush, it has what technically is termed "quality"- a rare and precious ingredient in any painting. Its atmosphere is a convincing proof of the artist's ability for it reeks with the misty loveliness of the lagoons.

From an English collection, where it was placed many years ago by Messrs. Cottier \& Company. 


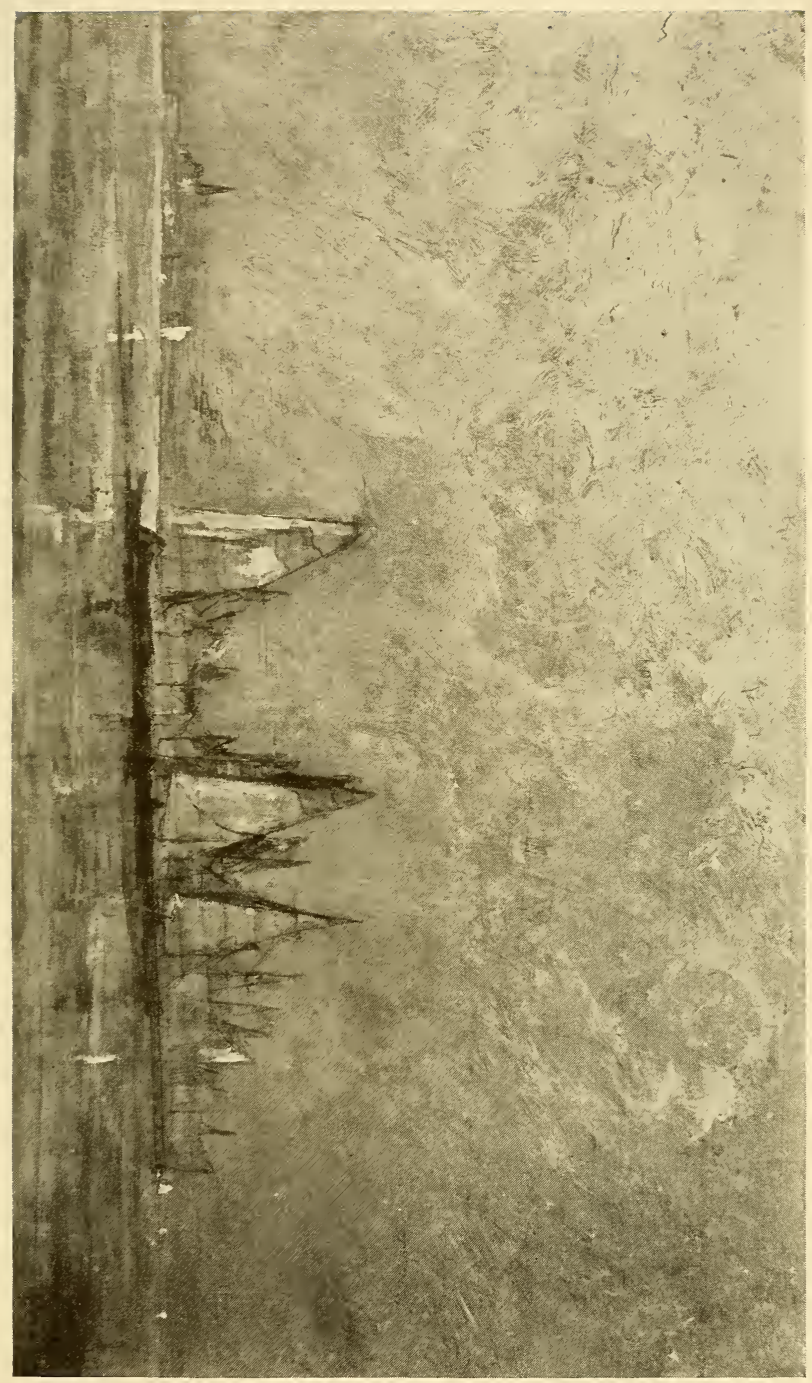




\section{GIRL BLOWING BUBBLES \\ By ROBERT LOFTIN NEWMAN}

Canvas. 20 inches bigh by 16 inches wide. Signed at the lower left, "R. L. Newman."

An altogether unusual and interesting color scheme that emphasizes the idea of mystery which is suggested by the enveloping shadows and the inarticulate curiosity of the watching dogs. The figure of the child, the green-covered couch, on which she rests her hand, and the two dogs are merely sketched in sufficiently to serve as notes in an exquisite color harmony which is at once attractive to the last degree and highly expressive. The picture is a finished work of art in that it is an arresting piece of rich and satisfying color. 


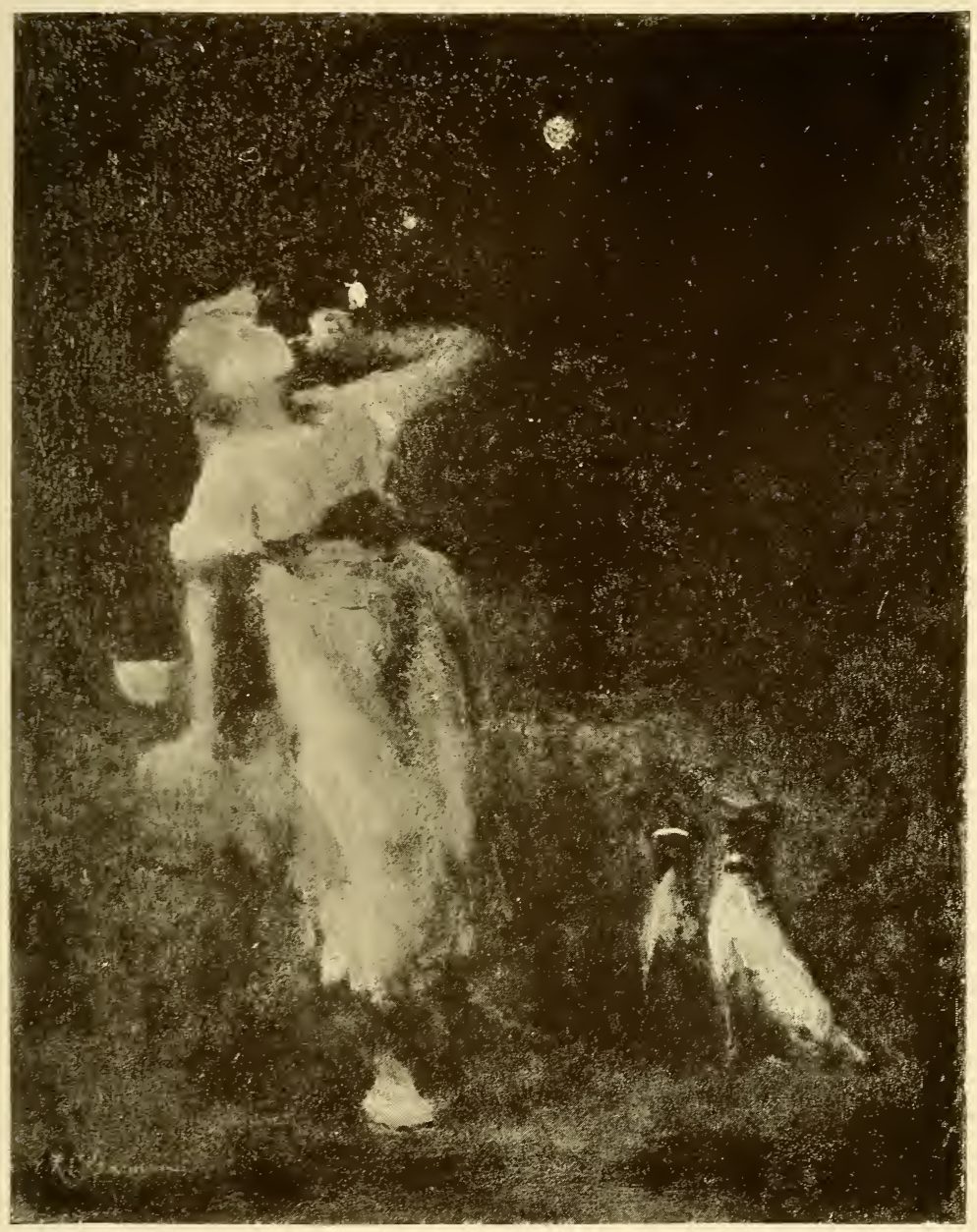




\section{HAYMAKING \\ By' WINSLOW HOMER}

Cancas. I 6 inches bigh by I inches wide. Signed and dated at lower left "Homer 64."

Probably the finest of Homer's early farm pictures, full of sunlight and full of meaning for anyone who appreciates the country. It is charming in color, the figure in blue overalls and red shirt, a soft blue sky above and the gray-gold of the hay in the foreground. Technically it is unquestionably the best of his early "oils" - a fact that is evidenced by its present pristine state after the lapse of more than sixty years.

\section{THE OCTOPUS \\ B) JOHN S. SARGENT}

Canvas. 16 $1 / 8$ inches bigh by $127 / 8$ inches wide. Signed and dated across the top of the picture, "John S. Sargent I 875 ." Inscribed in ink on back of the canc'as by the artist,

"painted on board of a fisbing-smack
in Brittany by Jobn S. Sargent in I $875 . "$

Formerly the property of Mr. Charles Knoedler and accompanied by a letter from the artist to him reading: "All I can remember about that 'Octopus' is that it was a sketch done on the deck of a fishing boat in Brittany when I was about 19 years old. I am glad you like it well enough to have bought it for yourself. I will sign it for you if you like." 


\section{SMALL PAINTINGS BY THE GREAT AMERICAN MASTERS}

\section{ALBERT P. RYDER}

DANCING NYMPHS. Panel. 6 inches bigh by $71 / 4$ inches wide. Unsigned.

SHEEP IN THE FIELD. Panel. $23 / 4$ inches bigh by $8 \mathrm{1} / 4$ inches wide. Signed on the back, "A. P. Ryder."

Formerly the property of Mr. Nestor Sanborn, a personal friend of Ryder.

\section{HOMER D. MARTIN}

AUTUMN LANDSCAPE. 6 inches high by ro inches wide. Signed "H. D. Martin."

LAKE PLACID. Academy board. Io inches high by $133 / 4$ inches wide. Signed and dated, "H. D. Martin'79."

\section{WINSLOW HOMER}

GOING ASHORE. Panel. s inches high by $81 / 4$ inches wide. Signed and dated on prow of boat, "W. Homer i 875 ."

Formerly the property of Smith Van Buren, the son of President Van Buren.

\section{R. A. BLAKELOCK}

INLAND LAKE. Canvas. 4 inches bigh by $61 / 2$ inches wide. Signed "R. A. Blakelock."

GOLDEN AFTERNOON. Canvas. 6 inches bigh by 8 inches wide. Signed "R. A. Blakelock."

MOONRISE. Panel. 6 inches bigh by 8 inches wide. Signature lower right now indistinguishable.

From the Thomas B. Clarke collection 1899.

MOONLIGHT AT MIDNIGHT. Panel. $53 / 4$ inches bigh by $103 / 4$ inches wide. Signed "R. A. Blakelock."

\section{WILLIAM M. HUNT}

NEW ENGLAND VILLAGE. Academy board. 5 inches bigh by $63 / 4$ inches wide. Signed with the monogram "WMH." 


\section{JOHN LAFARGE}

KNEELING ANGEL. Water color on paper. About 6 incloes bigh by s inches wide. Signed with initials "LF."

\section{GEORGE INNESS}

PASTORAL SCENE. Canvas. $61 / 2$ inclues bigh by $83 / 4$ inches wide. Signed and dated on back, "G. Inness I $857 . "$

Formerly the property of George $\mathrm{H}$. Smillie, the American engraver.

\section{ALEXANDER H. WYANT}

LANDSCAPE. Canvas. $4^{1 / 4}$ inches bigh by $71 / 2$ incloes wide. Signed "A. H. W'ant."

\section{PORTRAIT MINIATURES}

JAMES PEALE

SAMUEL F. B. MORSE

HENRY C. SHUMWAY

JOHN W. JARVIS

JOHN RAMAGE

JAMES S. ELLSWORTH

DANIEL WAGNER

EDWIN W. GOODWIN
MERIVA CARPENTER

Jacob Hull, 1783-r83i, of Philadelphia. Sold Signed and dated, J. P., I 850 .

Mrs. Whitehouse.

Unidentified Gentleman and his Wife. So $7 d$ Each miniature signed, Shumuay.

Unidertified Gentleman.

Delford Carpenter. I800-I842. Brother of the artist.

Signed and dated on the back.

Unidentified Gentleman.

Unidentified Elderly Lady.

Nathaniel Wagner, brother of the artist.

Inscribed and dated by the artist.

Unidentified Young Man.

Signed.

MAREIANA CARPENTER Henri Lamoran Carpenter, aged I 2 years. Brother of the artist.

Signed and dated, 1844. 


\section{EARLY AMERICAN PORTRAITURE, By FREDERIC FAIRCHILD SHERMAN}

Quarto. With 2 full-page photogravure plates and 36 pages of balftone reproductions. Limited edition of 250 copies. $\$ 20.00$ net, delivered.

Essays on Stuart's Portraits of Washington, John Trumbull, The Portraits of Washington from Life, Samuel L. Waldo and William Jewett, John Singleton Copley as a Miniaturist, Richard Jennys, Nathaniel Jocelyn, Samuel F. B. Morse, Asher B. Durand, Robert Fulton, Minor Portraitists of the Nineteenth Century, Cabinet Portraits by Early American Artists, A Water color Portrait by Paul Revere and Frank Duveneck.

\section{JOHN RAMAGE}

\section{A Brief Biograpbical Sketch, together with}

\section{A List of Ramage's Portrait Miniatures}

By FREDERIC FAIRCHILD SHERMAN

Small quarto. With 35 of the artist's miniatures reproduced in photogravure. Limited edition of 165 copies only at \$17.50 net, delivered.

The list of miniatures, thirty-seven in all, includes detailed descriptions of each portrait, with, in most cases, an historical sketch of the subject, and, occasionally, aistory of the miniature itself. A complete series of excellent photogravure reproductions of the listed miniatures is included and offers a most satisfactory survey of the artist's style and accomplishment.

- Antiques.

\section{ROBERT FIELD}

Portrait Painter in Oils, Miniature, Water Color and Pastel, and Engraver

\section{By HARRY PIERS}

Quarto. With four full-page plates in photogravure and thirtyfive full-page balftone plates. Limited edition of 325 copies at $\$ 30.00$ net, delivered.

An effectively arranged and very thorough study of the artist. The facts of his life, the characteristics of his style and technique, and a descriptive catalogue of all his known works are the principal divisions of the book. There are also fifty-three splendid reproductions of his paintings.

-International Studio.

\section{CHARLES FRASER}

\section{By ALICE R. HUGER SMITH and D. E. HUGER SMITH}

Quarto. With four miniatures reproduced in photogravure and about fifty in balftone. Limited edition of 325 copies at $\$ 15.00$ net, delivered.

Mr. and Mrs. Smith have done a valuable service in studying the paintings of a too little-known miniaturist and in selecting and annotating typical examples from the range of his work.

-The Nation.

\section{FREDERIC FAIRCHILD SHERMAN, PUBLISHER}




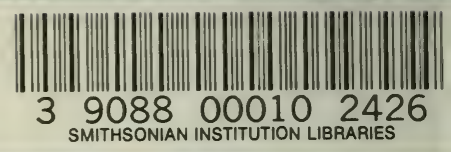

